\title{
The effect of pretreatment using hydrochloric acid on the characteristics of buffalo hide gelatin
}

\author{
S. Mulyani ${ }^{1,3}$, F. M. C. S. Setyabudi ${ }^{2}$, Y. Pranoto ${ }^{2}$ and U. Santoso ${ }^{2}$ \\ ${ }^{1}$ Doctoral Program, Faculty of Agricultural Technology, Gadjah Mada University, \\ Jl. Flora No.1, Bulaksumur, Yogyakarta 55281 - Indonesia \\ ${ }^{2}$ Faculty of Agricultural Technology, Gadjah Mada University, \\ Jl. Flora No.1, Bulaksumur, Yogyakarta 55281 - Indonesia \\ ${ }^{3}$ Permanent Address: Faculty of Animal and Agricultural Sciences, Diponegoro University, \\ Tembalang Campus, Semarang 50275 - Indonesia \\ CorrespondingE-mail : umar_s@ugm.ac.id
}

Received August 31, 2016; Accepted January 04, 2017

\begin{abstract}
ABSTRAK
Tujuan penelitian adalah untuk mengidentifikasi variasi konsentrasi asam klorida terhadap yield dan sifat fisikokimia gelatin kulit kerbau. Design penelitian menggunakan Rancangan Acak Lengkap, dengan perlakuan variasi konsentrasi asam klorida $0.3 \mathrm{M}, 0.6 \mathrm{M}, 0.9 \mathrm{M}, 1.2 \mathrm{M}$ dan $1.5 \mathrm{M}$, ulangan sebanyak empat kali, dilanjutkan uji beda nyata terkecil. Yield, kekuatan gel, viskositas, pH dan intensitas warna merah gelatin dipengaruhi $(\mathrm{P}<0.05)$ oleh variasi konsentrasi $\mathrm{HCl}$. Yield tertinggi (29.17\%) diperoleh pada konsentrasi 0.9M. Kekuatan gel dan viskositas tertinggi pada konsentrasi 1.2M, masing-masing $293.41 \mathrm{~g}$ bloom dan $22.17 \mathrm{cP}$. Gelatin kulit kerbau mempuyai pH 5.08 -5.52. Tingkat kecerahan warna gelatin $\left(\mathrm{L}^{*}\right) 69.92$ - 70.97, sedangkan warna merah $\left(\mathrm{a}^{*}\right)$ 0.55-1.54 dan kuning (b*) $17.54-19.59$. Kadar air gelatin $7.05 \pm 0.07-8.92 \pm 0.06 \%$, kadar protein $83.38 \pm 0.06-91.11 \pm 0.03 \%$ dan kadar abu $0.53 \pm 0.04-1.23 \pm 0.09 \%$. Berdasarkan absorbsi spectra fourier transform infrared (FTIR) terdeteksi empat area amida yaitu amida A (3402.43 - $3448.72 \mathrm{~cm}-1)$, amida I $(1635.65 \mathrm{~cm}-1)$, amida II $(1527.62 \mathrm{~cm}-1)$ dan amida III $(1242.16 \mathrm{~cm}-1)$. Variasi konsentrasi $\mathrm{HCl}$ mempengaruhi yield, karakteristik dan struktur sekunder gelatin kulit kerbau. Konsentrasi 0.9M merupakan kondisi optimum untuk memperoleh yield tertinggi. Karakteristik gelatin kulit kerbau dengan pretreatment menggunakan asam klorida telah memenuhi standar kualitas Gelatin Manufacturing Institute of America (2012) .
\end{abstract}

Kata kunci : asam klorida; gelatin, kulit kerbau, pretreatment, yield

\begin{abstract}
The objective of the research was to identify the effect of the concentration of hydrochloric acid $(\mathrm{HCl})$ on yield and the characteristics of gelatin from buffalo hide. A completely randomized design was used with various concentrations of $\mathrm{HCl}$ treatment $0.3 \mathrm{M}, 0.6 \mathrm{M}, 0.9 \mathrm{M}$, $1.2 \mathrm{M}$ and $1.5 \mathrm{M}$, and four times replication, followed by least significant difference test. The $\mathrm{HCl}$ concentration gave significantly effect $(\mathrm{P}<0.05)$ on yield, viscosity, $\mathrm{pH}$, gel strength and redness of gelatin. The highest yield $(29.17 \%)$ was obtained at a concentration of $\mathrm{HCl} 0.9 \mathrm{M}$. The highest gel strength and viscosity at concentration of $1.2 \mathrm{M}$, were $293.41 \mathrm{~g}$ bloom and $22.17 \mathrm{cp}$, respectively. The $\mathrm{pH}$ of the gelatin were 5.08 to 5.52. The lightness level ( $\mathrm{L}^{*}$ ) was 69.92-70.97, whereas the redness ranged $\left(\mathrm{a}^{*}\right)$ from 0.55 to 1.54 and the yellowness ranged
\end{abstract}


(b*) from 17.54 to 19.59. The moisture, protein and ash concentrations of gelatin were 7.05 $\pm 0.07-$ $8.92 \pm 0.06 \%$, protein content of $83.38 \pm 0.06-91.11 \pm 0.03 \%$, and the ash content $0.53 \pm 0.04$ to $1.23 \pm$ $0.09 \%$, respectively. Based on the spectra absorption of infrared were detected four areas amides: amide A (3402.43-3448.72 cm-1), amide I (1635.65 cm-1), amide II (1527.62 cm-1) and amide III (1242.16 $\mathrm{cm}-1)$. The differences in the concentration of $\mathrm{HCl}$ had impact on yield, characteristics and secondary structure of buffalo hide gelatin. The $\mathrm{HCl}$ concentration at $0.9 \mathrm{M}$ was the optimum condition to obtain the highest yield. The characteristics of buffalo hide gelatin after pretreatment using hydrochloric acid had met the standards of GMIA (2012) .

Keywords: Hydrochloric acid, gelatin, buffalo hide, pretreatment, yield

\section{INTRODUCTION}

Buffalo is the one of tropical livestock producing skin by-product that may be used as raw material for producing gelatin. The skin byproduct of buffalo had thick and strong structure because slaughtering age buffalo was older than slaughtering age of cows and commonly used as working livestock (Huda et al., 2011). The thickness of skin by-product is 6-8 $\mathrm{mm}$ with approximately $11.5 \%$ of the animal live weight (Spanghero et al., 2004). The thickness and firmness of skin by-product indicated. A high collagen fibers. A high collagen of the hide is supported by the high pyrrolidine group of amino acid hydroxyproline.. The pyrrolidine group attributes the collagen with a high thermal stability (Haugh and Draget, 2009), so heat extraction only could not optimize the extraction process. Therefore, acid pretreatment process is required to optimize the extraction process (Niu et al., 2013).

The acid pretreatment results in increasing weak intermolecular and intra- molecular structural bond in the skin collagen protein because of partial breakdown of the amino acid bond chain (Kolodziejska et al., 2007). This condition is used in the extraction process resulting in collagen solubility (Johnston-Banks, 1990). Acid pretreatment at different acid concentrations has an impact on yield and gel strength (Ahmed and Benjakul, 2011; Nikoo et al., 2014). An acid helps the release and dissolve of some proteins, fat and other components of collagen. This also disturbes cross-interaction molecules of the collagen thereby increasing the efficiency of the extraction. Hydrochloric acid is a type of strong acid that could be dissociated perpectly, thus producing many hydrogen ions to break crosslinks in collagen molecules. Hydrochloric acid requires lower concentration to achieve an optimal extraction condition compared to other type of acid (Niu et al., 2013).More higher acid concentration may cause overhydrolysis of collagen molecules and losing protein during washing process (Binsi et al., 2009; Jamilah and Harvinder, 2002). The hydrolysis rate of the collagen molecules influences the yield and characteristics of gelatin. Therefore, the optimization of the acid concentration prior to the extraction is required to avoid over-hydrolysis. This study was aimed to clarify the effect of the concentration of the $\mathrm{HCl}$ concentration on the gelatin yield and the characteristics of buffalo hide.

\section{MATERIALS AND METHODS}

\section{The extraction of buffalo hide gelatin}

Wet salt preserved buffalo hide was obtained from CV. Panji Jaya in Cegoroyoso village of Pleret sub district of Bantul, Yogyakarta with the criteria of male buffalo of 2-3 years. The hide washed using tap water and then the hide was soaked in $2 \%(\mathrm{w} / \mathrm{v})$ camphor solution till the hair was completely removed. Subsequently, the processed hide was scratched to remove the hair and the fat and then was washed using tap water till its $\mathrm{pH}$ was 7-7.5. After the removal of the hair and the fat, the processed hide was kept frozen at $-18^{\circ} \mathrm{C}$ (Said et al., 2011). Before the pretreatment, it was thawed at $4^{\circ} \mathrm{C}$ for 20 hours and cut into small pieces $(1 \mathrm{x} 1 \mathrm{~cm})$ (Ktari et al., 2014).

The gelatin from buffalo hide was extracted according to the method of Niu et al. (2013) with modification. The pieces of the buffalo hide were soaked in $0.5 \mathrm{M} \mathrm{NaOH}(1: 4 ; \mathrm{w} / \mathrm{v})$ for 2 hours. Subsequently, the hide was soaked in $\mathrm{HCl}$ at the concentrations of $0.3 \mathrm{M}, 0.6 \mathrm{M}, 0.9 \mathrm{M}, \quad 1.2 \mathrm{M}$ and $1.5 \mathrm{M}(1: 4 ; \mathrm{w} / \mathrm{v})$. The processed hide was drained and washed six times till reaching the $\mathrm{pH}$ 5-6. The pretreated hide was extracted with distillated water $(1: 4 ; \mathrm{w} / \mathrm{v})$ at $65^{\circ} \mathrm{C}$ in water bath (Memmert WNB7-45 type) for 5 hours and then followed in similar manner at $70^{\circ} \mathrm{C}$ for the second step extraction. The extracting result was roughly 
sieved and dried using cabinet drier at $50-55^{\circ} \mathrm{C}$ for 48 hours. The extracted gelatin yield was calculated using formula of Ktari et al. (2014):

$$
\text { Yield }(\%)=\frac{\text { Dry gelatin we ight }}{\text { Fresh hide weight }} \times 100
$$

\section{Proximate Analysis of Hide and Gelatin}

The moisture, protein, and ash contents of the buffalo hide and gelatin were determined using proximate analysis following AOAC guideline (2005). Analysis of each proximate was done in three replication.

\section{Determination of Hydroxiproline}

A hundred milligram samples of skin or gelatin was crushed and hydrolyzed by adding $5 \mathrm{ml} 6 \mathrm{~N} \mathrm{HCl}$ for 12 hours at $110^{\circ} \mathrm{C}$ in drybath. Then, $\mathrm{NaOH} 6 \mathrm{~N}$ was used to neutralize the samples. Two $\mathrm{ml}$ acetate or citrate buffer and 0.3 $\mathrm{M} \mathrm{NaCl}$ were added till $25 \mathrm{ml}$ volume was reached. The solution was transferred to the $300 \mu 1$ isopropanol and oxidant solution containing testing flask. At this time the mixture was quickly mixed for 4 minutes, and then was added $4 \mathrm{ml}$ of Ehrlich's solution in $3 \mathrm{ml}$ of $60 \%$ acid per chloride $(\mathrm{v} / \mathrm{v})$. The solution mixture was shake for 25 minutes in water bath $\left(60^{\circ} \mathrm{C}\right)$. The optical density of solution mixture was measured using a spectrophotometer at wavelength of 660 $\mathrm{nm}$. The calculation of hydroxyproline content was followed by standard hydrokxyproline solution curve (Sigma Chemical).

\section{Determination of Gel Strength}

Gelatin powder $(6.67 \mathrm{~g})$ was dissolved in $100 \mathrm{~mL}$ of distilled water $(6.67 \%$; w/v) and was stirred using magnetic stirrer and then heated at $60^{\circ} \mathrm{C}$ for $15 \mathrm{~min}$ and incubated $16-18$ hours at $10^{\circ} \mathrm{C}$. Subsequently, it was measured using texture analyzer TA-XT plus HD (Stable Micro System Ltd., UK) at the probe speed of $0.5 \mathrm{~mm} / \mathrm{sec}$ and 4 mm depth (Benjakul, et al, 2009).

\section{Determination of Acidity ( $\mathrm{pH}$ )}

Zero point two gram sample was weighted, dispersed into $20 \mathrm{ml}$ of distilled water at $80^{\circ} \mathrm{C}$, and homogenized using magnetic stirrer. The acidity of solution was measured using $\mathrm{pH}$ meter (British Standard 757).

\section{Measurement of Color}

Chromameter (Konika Minolta Sensing, INC, Japan) with the Hunter system and expressed in $\mathrm{L}, \mathrm{a}$, and $\mathrm{b}$ value was used to measure the color of gelatin. The $\mathrm{L}$ value for the lightness were in the range of $100=$ white and $0=$ black. The a values were in the range of -50 (green) and +50 (red). The $\mathrm{b}$ values were in the range -50 (blue) and (yellow) (Jamilah and Harvinder, 2002).

\section{Determination of Fourier Transform Infrared (FTIR) Spectroscopy}

Gelatin powder $(2 \mathrm{mg})$ was made pieces in $100 \mathrm{mg}$ of kalium bromide $(\mathrm{KBr})$. The sample strip was read through FTIR (Shimadzu PC-8201) in the range of wave number 4000-650 cm-1 (Kaewruang et al., 2013).

\section{Statistical Analysis}

This study was designed using complete random design with various $\mathrm{HCl}$ concentration as treatments with four replicates. The Analysis of variance and least significant difference test (Steel and Torri, 1980) were performed using SPSS 20.0 for Windows. Especially for proximate, hydroxyproline and FTIR were determined using descriptive analysis based on the average mean with three times replicates.

\section{RESULTS AND DISCUSSIONS}

\section{Yield}

Yield is often related to the extraction efficiency in gelatin production. The increasing high yield is indicative of production process efficiency (Kolodziejska et al., 2007). The gelatin extraction yield at various $\mathrm{HCl}$ concentrations in the pretreatment process are shown in Table 1. The values were in the range of $14.67 \%$ to $29.17 \%$, with the highest yield at the $\mathrm{HCl}$ concentration of $0.9 \mathrm{M}$. The values decreased to $25.59 \%$ and $24.53 \%$, when the $\mathrm{HCl}$ concentration was increased up to 1.2 and $1.5 \mathrm{M}$.

The $\mathrm{HCl}$ concentrations gave significantly affect $(\mathrm{P}<0.05)$ on the yield of buffalo hide gelatin. Acid pretreatment is required as $\mathrm{H}^{+}$ion provider that plays an important role in breaking both intra and intermolecular bonds of collagen, so collagen is easily dissolve in water. The increasing acid concentration was followed by the increased $\mathrm{H}^{+}$concentration in solution, finally the collagen hydrolysis process was accelerated. The higher hydrolysis rate caused the triple helix collagen breakdown into more bigger $\alpha, \beta$ and $\Upsilon$ chains. In other words the collagen conversion into gelatin increased in accordance with the 
Table 1. Yield and the Characteristics of Buffalo Hide Gelatin by Pretreatment Using $\mathrm{HCl}$

\begin{tabular}{|c|c|c|c|c|c|c|c|}
\hline \multirow{2}{*}{$\begin{array}{l}\text { Concentration } \\
\text { of HCL }\end{array}$} & \multirow{2}{*}{ Yield* $(\%)$} & \multirow{2}{*}{$\begin{array}{l}\text { Gel Strength } \\
\text { (g bloom) }\end{array}$} & \multirow{2}{*}{$\begin{array}{l}\text { Viscosity } \\
\text { (cP) }\end{array}$} & \multirow{2}{*}{$\mathrm{pH}^{*}$} & \multicolumn{3}{|c|}{ Measurement of Color } \\
\hline & & & & & $\mathrm{L}^{\mathrm{ns}}$ & $a^{*}$ & $b^{\text {ns }}$ \\
\hline $0.3 \mathrm{M}$ & $14.67 \pm 1.40^{\mathrm{c}}$ & $265.08 \pm 3.64^{\mathrm{b}}$ & $18.65 \pm 1.20^{\mathrm{ab}}$ & $5.52 \pm 0.03^{\mathrm{a}}$ & $69.92 \pm 1.94$ & $0.55 \pm 0.22^{\mathrm{a}}$ & $17.54 \pm 0.59$ \\
\hline $0.6 \mathrm{M}$ & $26.44 \pm 2.10^{\mathrm{b}}$ & $239.44 \pm 13.45^{\mathrm{c}}$ & $17.92 \pm 1.20^{\mathrm{b}}$ & $5.16 \pm 0.02^{\mathrm{b}}$ & $70.97 \pm 0.91$ & $1.54 \pm 0.19^{\mathrm{b}}$ & $18.90 \pm 0.58$ \\
\hline $0.9 \mathrm{M}$ & $29.17 \pm 2.10^{\mathrm{a}}$ & $242.35 \pm 12.90^{\mathrm{c}}$ & $16.37 \pm 1.50^{\mathrm{b}}$ & $5.15 \pm 0.05^{\mathrm{bc}}$ & $70.66 \pm 1.46$ & $1.51 \pm 0.13^{\mathrm{b}}$ & $18.14 \pm 1.52$ \\
\hline $1.2 \mathrm{M}$ & $25.59 \pm 0.80^{\mathrm{b}}$ & $293.41 \pm 7.30^{\mathrm{a}}$ & $22.17 \pm 1.70^{\mathrm{a}}$ & $5.09 \pm 0.04^{\mathrm{c}}$ & $70.55 \pm 0.47$ & $1.21 \pm 0.56^{\mathrm{b}}$ & $19.59 \pm 1.80$ \\
\hline $1.5 \mathrm{M}$ & $24.53 \pm 0.90^{\mathrm{b}}$ & $248.94 \pm 13.45^{\mathrm{bc}}$ & $18.23 \pm 2.80^{\mathrm{ab}}$ & $5.08 \pm 0.03^{\mathrm{c}}$ & $70.82 \pm 0.83$ & $1.27 \pm 0.98^{\mathrm{b}}$ & $17.87 \pm 1.24$ \\
\hline
\end{tabular}

* Means within the same column followed by different superscript are significant different $(\mathrm{P}<0.05)$; ns = nonsignificant $(\mathrm{P}>0.05)$. L: lightness, a: redness, b; yellowness

increasing yield value. On the contrary, the increase in the $\mathrm{HCl}$ concentration more than $0.9 \mathrm{M}$ resulted in the decrease in the yield. Continuing hydrolysis process may cause more shorter collagen molecule chain and hence there were many dissolved collagen in the washing process. Once an optimum condition has been met, the increase in the acid concentration would decrease the gelatin yield because of the over-hydrolysis of the collagen and there were many proteins lost in the washing process (Niu et al., 2013: Jamilah and Harvinder, 2002).

\section{Chemical Composition of Hide and Gelatin}

The composition of the hide and the gelatin from buffalo was represented in the Table 2. The raw material of the wet salt preserved buffalo hide has gone through the process of soaking, so that it looked like fresh skin. Said et al. (2011) reported that fresh skin contained $64 \%$ moisture, $33 \%$ protein and $0.2 \%$ mineral. Alfaro et al. (2014) suggested that the protein content in the hide described maximum collagen content found in skin tissue.

In general, the hydroxyproline content of the buffalo gelatin was lower than the hidroxyproline buffalo hide ( $\%$ dry matter). The collagen conversion process into gelatin was carried out through pretreatment and extraction process at 65$70^{\circ} \mathrm{C}$ so that the hydrolysis process caused the decrease in the hydroxyproline content.

The moisture content of gelatin tended to diminish by the increasing $\mathrm{HCl}$ concentration used in the pretreatment process. The acid treatment brokedown both the intra- and intermolecular collagen crosslink so that the collagen structure became more open and weak. The water holding capacity lessened and increased the quantity of water evaporation during drying process (Sompie et al. 2015). The moisture of buffalo hide gelatin ranged from $7.05 \pm 0.07$ to $8.92 \pm 0.06 \%$. These value were lower than the results of Alfaro et al. (2014) and standard commercial gelatin is 9-14\% (Eastoe and Leach, 1977).

The protein content of gelatin directly related to the gel strength and viscosity (Said et al., 2011). The protein content of buffalo hide gelatin were in the range of $83.38 \pm 0.06$ to $91.11 \pm$ $0.03 \%$. (Table 2). This result was almost consistent with other studies. Said et al. (2011) examined the gelatin of goat skin, the protein content were in the range of 89.37 $\pm 1.19 \%$ - $90.74 \pm 1.82 \%$. Sompie et al (2015) reported that gelatin from pig skin, were in the range of $86.03-89.22 \%$. This result was also similar to commercial gelatin approximately at 89.63\% (Pranoto et al., 2006). The collagen dissolving rate is influenced by the material and time used for the pretreatment process (Wang et al., 2008; Said et al., 2011). The protein content of gelatin from buffalo hide increased from $0.3 \mathrm{M}$ to $0.6 \mathrm{M}$ and $0.9 \mathrm{M}$. The increase in $\mathrm{HCl}$ concentration resulted more broken crosslink of both intra and intermolecular collagen that there are many proteins dissolved in the extraction process. The big number of the dissolved protein caused the increase in the protein content of gelatin. At the concentration of $1.2 \mathrm{M}$ and $1.5 \mathrm{M}$ the protein content did not further increase because the optimum concentration has been met. The increase in the acid concentration would 
Table 2. Chemical Composition of Hide and Gelatin from Buffalo by Pretreatment Using $\mathrm{HCl}$

\begin{tabular}{lrrrrrr}
\hline \multirow{2}{*}{ Composition (\%) } & \multirow{2}{*}{ Buffalo Hide } & \multicolumn{5}{c}{ Buffalo Hide Gelatin } \\
\cline { 3 - 7 } & & $\mathrm{HCl} \mathrm{0.3 \textrm {M }}$ & $\mathrm{HCl} \mathrm{0.6 \textrm {M }}$ & $\mathrm{HCl} \mathrm{0.9M}$ & $\mathrm{HCl} 1.2 \mathrm{M}$ & $\mathrm{HCl} 1.5 \mathrm{M}$ \\
\hline Moisture & $68.62 \pm 0.13$ & $8.92 \pm 0.06$ & $7.41 \pm 0.05$ & $7.09 \pm 0.01$ & $7.05 \pm 0.08$ & $7.64 \pm 0.21$ \\
Protein & $30.22 \pm 0.06$ & $89.35 \pm 0.01$ & $83.38 \pm 0.06$ & $91.11 \pm 0.03$ & $90.93 \pm 0.01$ & $90.89 \pm 0.03$ \\
Ash & $0.72 \pm 0.01$ & $1.23 \pm 0.09$ & $0.87 \pm 0.07$ & $0.56 \pm 0.01$ & $0.59 \pm 0.04$ & $0.53 \pm 0.04$ \\
Hydroxy-prolin & $0.25 \pm 0.04$ & $2.18 \pm 0.02$ & $0.71 \pm 0.02$ & $0.44 \pm 0.01$ & $0.46 \pm 0.01$ & $0.46 \pm 0.02$ \\
\hline
\end{tabular}

Results are means \pm standard deviation $(n=3)$

result in over-hydrolysis, therefore many proteins lost during washing (Niu et al., 2013; Sompie et al., 2015).

The gelatin extract from buffalo hide had the ash content approximately from $0.53 \pm 0.04$ to $1.23 \pm 0.09 \%$. These valus met GMIA standard, ranging from $0.3-2.0 \%$ and the maximum value is $2.6 \%$ recommended by Muyonga et al. (2004) The highest ash content found in the treatment at the $\mathrm{HCl}$ concentration of $0.3 \mathrm{M}$, and then decreasing at the $\mathrm{HCl}$ concentration of $0.6 \mathrm{M}$ and $0.9 \mathrm{M}$. Low ash content is indicative of good quality gelatin extraction process (Uriarte et al., 2011; Chandra and Shamasundar et al., 2015).

\section{Gel Strength}

Gel strength is a key parameter in the determination of gelatin quality. The gel strength indicates the capability of gelatin to change from gel phase into sol phase and vice versa (Kusumawati et al., 2008). The value of buffalo hide gelatin at the $\mathrm{HCl}$ concentration of $0.3 \mathrm{M}$ to $1.5 \mathrm{M}$ was in the range of 239.44 $293.41 \mathrm{~g}$ bloom.

The results of the measurement of the gel strength described that the $\mathrm{HCl}$ concentrations had significant impact $(\mathrm{P}<0.05)$ on the gel strength (Table 1). The $\mathrm{HCl}$ concentration of 1.2 $M$ showed the highest gel strength value (293.41 $\pm 0.73 \mathrm{~g}$ bloom), while the gel strength value at the $\mathrm{HCl}$ concentration of $1.5 \mathrm{M}$ decreased to the same value those found at the $\mathrm{HCl}$ concentrations of 0.9 and $0.6 \mathrm{M}$. The concentration of pretreatment material had impact on the gelatin gel strength. High concentration of acid could cause a decrease in the gel strength (Ockerman and Hansen, 2000). At the concentration of $1.2 \mathrm{M}, \mathrm{HCl}$ brokedown amino acid polymer chain at the right limit. This improved the effect in formation process of gel. Subsequently, amino acid monomer chains joined to form a continuous three-dimensional structures and bond water to form compact gel structure. The difference in the gelatin gel strength related to amino acid chain length, imino acid composition (prolin and hydroxyprolin), the concentration of gelatin and the distribution of molecule weight (Arsenen and Gildberg, 2007; Karim and Bhat, 2009). Gelatin with long chains had high gel strength values. The values have met the GMIA standard (2012), which were 50-300 g bloom to be applicable in general industry.

\section{Degree of acidity (pH)}

The $\mathrm{HCl}$ concentration significantly effected $(\mathrm{P}<0.05)$ on gelatin acidity (Table 1$)$. The Increasing $\mathrm{HCl}$ concentration, degreased in $\mathrm{pH}$ of gelatin, at $1.2 \mathrm{M}$ and $1.5 \mathrm{M}$ of $\mathrm{HCl}$ concentration, the $\mathrm{pH}$ was unaffected significantly. The higher $\mathrm{HCl}$ concentration caused a progressive increase in the number of hydrogen ions (Kusumawati et al., 2008). The $\mathrm{pH}$ value at the $\mathrm{HCl}$ concentrations of $0.3 \mathrm{M}$ to $1.5 \mathrm{M}$ was in the range of $5.08-5.52$. It still met industrial standard (GMIA, 2012), which were $3.8-6.0$.

\section{Viscosity}

The viscosity of the buffalo hide gelatin were in the range of 16.37 to $22.17 \mathrm{cp}$. The values have met GMIA quality standard (2012) for food industry, which were $1.5-7.5 \mathrm{cp}$. The $\mathrm{HCl}$ concentration gave significantly effect $(\mathrm{P}<0.05)$ on the viscosity. One of the influencing factors of the gelatin viscosity is $\mathrm{pH}$ value (Kusumawati et al., 2008). Considering the $\mathrm{pH}$ values summarized in Table 1, the $\mathrm{pH}$ of the buffalo hide gelatin was in the range that still met industrial quality standard and optimal $\mathrm{pH}$ for gelatin production. 
Jamilah and Harvinder (2002) suggested that the viscosity of the gelatin could be increased by extracting the gelatin at the $\mathrm{pH}$ of 3-10.5. In the range of the optimum $\mathrm{pH}$ for collagen hydrolysis (the breaking of the collagen chain took place in limit of polypeptide) the protein chains are still long and the gelatin viscosity was high (Said et al., 2011; Pelu et al., 1998).

\section{Color}

The color and the lightness of the gelatin present esthetic characteristics influencing the acceptability and the applicability of the gelatin. In general, the color of the gelatin did not have any significant impact on its function (Table 1). However, more light colors are more liked because they provided more flexibility to be mixed into certain food system (Rahman and Jamalulain, 2012; Shyni et al., 2014). The results of the measurement of the colors of the buffalo hide gelatin were expressed in brightness values $\left(\mathrm{L}^{*}\right)$, redness intensity $\left(\mathrm{a}^{*}\right)$ and yellowness intensity $\left(b^{*}\right)$. The $\mathrm{HCl}$ concentration did not have any significant impact $(\mathrm{P}>0.05)$ on the brightness value or on the yellowness intensity, but it had significant impact $(\mathrm{P}<0.05)$ on the intensity of the red color of the gelatin. The use of the $\mathrm{HCl}$ concentrations of $0.3-1.5 \mathrm{M}$ was still in the safe limit for pretreatment process. This means that though the hydrolysis process proceeding higher with the increase in the concentration of $\mathrm{H}^{+}$ (more higher $\mathrm{HCl}$ concentration), this was still in the expected limit. There was an increase in the red color intensity at $0.6 \mathrm{M}$ of $\mathrm{HCl}$ concentration as compared to $0.3 \mathrm{M}$, but this was not significantly different $(\mathrm{P}>0.05)$ with $0.9 \mathrm{M}$, $1.2 \mathrm{M}$, and $1.5 \mathrm{M}$. The higher collagen hydrolysis caused the increasing supply of free amino group. The amino group reacts to the skin carbonyl compound is non- enzymatic browning reaction this cause the increase in the redness and yellowness of the gelatin (Nagarajan et al., 2012; Sae-Law and Benjakul, 2015; Sae-Law et al., 2016).

\section{Fourier Transform Infrared (FTIR) Spectroscopy}

The FTIR is applied to observe the change in the functional group and the secondary structure of the gelatin (Muyonga et al., 2004; Kaewruang et al., 2013). Figure 1 shows the FTIR spectra of buffalo hide gelatin through the pretreatment with $\mathrm{HCl}$ at the various concentrations from 0.3 to $1.5 \mathrm{M}$. Muyonga et al., (2004) reported that there were four identified amide areas in the wave numbers of $3600-2300$ per $\mathrm{cm}$ (amide A), 1656 - 1644 per $\mathrm{cm}$ (amide I), 1560-1335 per $\mathrm{cm}$ (amide II) and $1240-670$ per $\mathrm{cm}$ (amide III).

The amide $\mathrm{A}$ of the buffalo hide gelatin at the $\mathrm{HCl}$ concentrations of $0.3 \mathrm{M}, 0.6 \mathrm{M}, 0.9 \mathrm{M}$, $1.2 \mathrm{M}$ and $1.5 \mathrm{M}$ were respectively detected in the

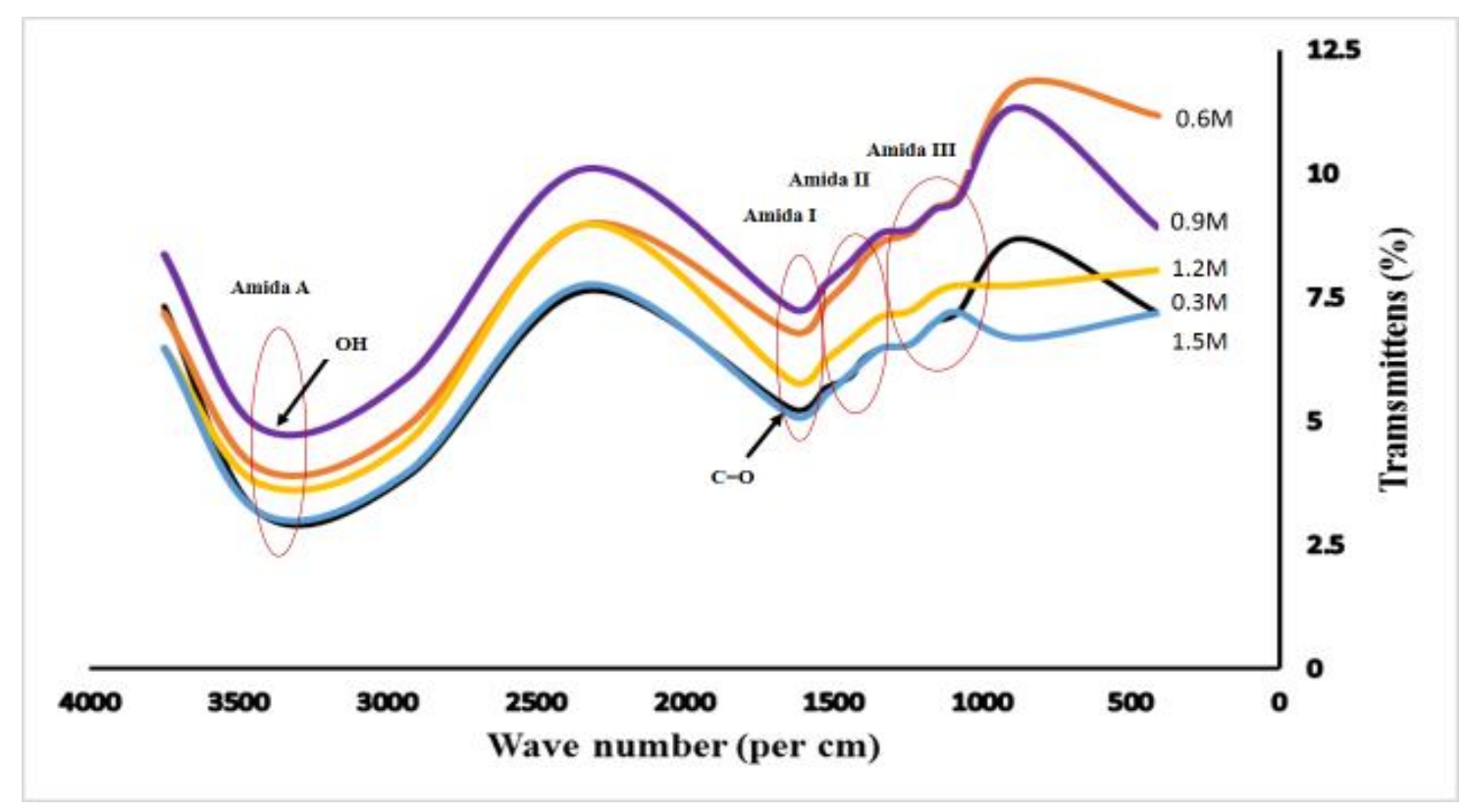

Figure 1. FTIR Spectra of Buffalo Hide Gelatin by Pretreatment using $\mathrm{HCl}$ 
wave numbers of 3402.43 per $\mathrm{cm}, 3425.58$ per $\mathrm{cm}, 3425.58$ per $\mathrm{cm}, 3448.72$ per $\mathrm{cm}$ and 3425.58 per $\mathrm{cm}$. The peak of the amide A related to the stretch of the group $\mathrm{N}-\mathrm{H}$ and was indicative of the existence of hydrogen bond. Vibration normally take place in the wave numbers of $3400-3440$ per $\mathrm{cm}$. The lower wave numbers indicated bigger molecular degradation of the gelatin. The degradation produces free amino group that interracts with other reactive groups (Kaewruang et al., 2013). The gelatin at the $\mathrm{HCl}$ concentration of $1.2 \mathrm{M}$ had amide A peak with the highest wave number (Figure 1). In other words, the molecular degradation was the smallest with the longest molecular chain that the viscosity value and the strength of the gel were the highest.

The amide I presents the stretch $\mathrm{C}=0$ or hydrogen bond in a pair with COO. The absorbing area of the amide $\mathrm{I}$ is often used to analyze protein secondary structure (Nagarajan et. al., 2012). The amide I of the buffalo hide gelatin at the $\mathrm{HCl}$ concentrations of $0.3 \mathrm{M}, 0.6 \mathrm{M}, 0.9 \mathrm{M}$, $1.2 \mathrm{M}$ and $1.5 \mathrm{M}$, respectively were detected in the same wave number of 1635.64 per $\mathrm{cm}$. Yakimates et al. (2005), Nagarajan et al. (2012) stated may represent the peak absorption took place in the wave number of 1633 per $\mathrm{cm}$ representing the characteristic of the coil structure of the gelatin. Concerning with transmission intensity, the gelatin at the highest $\mathrm{HCl}$ concentration of $0.9 \mathrm{M}$ experienced triple helix dispersal into coil structure whose quantity was the highest. Therefore, the pretreatment with the $\mathrm{HCl}$ at the concentration of $0.9 \mathrm{M}$ produced the highest yield (Table 1).

The amide II of the buffalo hide gelatin at the $\mathrm{HCl}$ concentrations of $0.3 \mathrm{M}, 0.6 \mathrm{M}, 0.9 \mathrm{M}$, $1.2 \mathrm{M}$, and $1.5 \mathrm{M}$ was detected in the range of the wave numbers of $1527.62-1342.46$ per $\mathrm{cm}$ (Figure 1). The absorption of the amida II takes place because of the vibration of the N-H group and the stretch of the group C-N (Nagarajan et al., 2012). The amide III was detected in the wave numbers of $1242.16-871.82$ per $\mathrm{cm}$. This showed the combination of the stretch peak of $\mathrm{C}-\mathrm{N}$ and the deformation of $\mathrm{N}-\mathrm{H}$ in the amide was observed as the absorbance of the group $\mathrm{CH} 2$ of the glycine backbone chain and the proline side chain. The gelatin at the $\mathrm{HCl}$ concentration of $0.9 \mathrm{M}$ was indicative of the highest transmittance intensity for both amide II and III. T $\mathrm{h}$ is indicated that the bigger random molecular structure may be exist because the a- helix transformation into coil random structure may take place more frequently with the increase in the acid concentration of $0.9 \mathrm{M}$. The change related to the loss of the triple helix structure as a result of collagen denaturizing into gelatin (Muyonga et al., 2004; Nagarajan et al., 2012).

\section{CONCLUSION}

The difference in $\mathrm{HCl}$ concentrations had impact on the yield, the characteristics and the secondary structure of the buffalo hide gelatin. The $\mathrm{HCl}$ concentration of $0.9 \mathrm{M}$ represented the optimum concentration to produce the highest yield. In general, the characteristics of the buffalo hide gelatin with the pretreatment process using HCL had the characteristics that met the GMIA standard.

\section{REFERENCES}

Lee, J.W., S.B. Choi, Y.H. Jung, J.F. Keown and L.D. Van Vleck. 2000. Parameter estimates for direct and maternal genetic effects on yearling, eighteen-month, and slaughter weights of Korean native cattle. J. Anim. Sci. 78:1414-1421.

Ahmad, M and S. Benjakul. 2011. Characteristics of gelatin from the skin of unicorn leatherjacket (Aluterus monoceros) as influenced by acid pretreatment and extraction time. Food Hydrocoll. 25:281-288

Alfaro, A.T., F. C. Biluca, C. Marquetti, I.B. Tonial and N.E.de Souza. 2014. African catfish (Clarias gariepinus) skin gelatin: Extraction optimization and physicalchemical properties. Food Res. Int. 65:416422

AOAC. 2005. Official Methods of Analyses Association (18 $8^{\text {th }}$ Ed.) Association of Analytical Chemist, Washington, D.C

Arsenen, J.A. and A.Gildberg. 2007. Extraction and characterization of gelatin from Atlantic salmon (Salmo salar) skin. Bioresour. Technol. 98 (1):53-57

Benjakul, S., K. Oungbho, W. Visessanguan, Y. Thiansilakul, and S. Roytrakul. 2009. Characteristic of gelatin from the skins of bigeye snapper, Priacanthus tayenus and Priachantus macracanthus. Food Chem. 116:445-451

Binsi, P.K., B.A. Shamasundar, A.O. Dileep, F. Badii and N.K. Howell. 2009. Rheological and functional properties of gelatin from the 
skin of Bigeye snapper (Priacanthus hamrur). Food Hydrocoll. 23: 132-145.

Chandra, M.V. and B.A. Shamasundar 2015. Rheological properties of gelatin from swim bladders of freshwater fish Catla catla. Food Hydrocoll. 48: 47-54

Eastoe, J.E. and AA. Leach 1977. Chemical Constitution of Gelatin. In: Ward AG, Courts A. editors. The Science and Technology of Gelatin. Academic Press, New York.

GMIA. 2012. Gelatin Handbook. Gelatin Manufacturers Institute of Amerika

Haug, I.J. and K.I. Draget. 2009. Gelatin in Handbook of Hydrocolloids. Norwegian University of Science and Technology (NTNU), Norway

Huda, N., A.A. Putra and R. Ahmad. 2011. Physicochemical and nutritional characteristics of Indonesian buffalo skin crackers. Int. J. Meat Sci. 1 (1): 36-51

Jamilah, B and K.G. Harvinder. 2002. Properties of gelatins from skins of fish black tilapia (Oreochromis mossambicus) and red tilapia (Oreochromis nilotica). Food Chem. 77:8184

Johnston-Bank, F.A. 1990. From Tannery to Table: An account of gelatin production. J. of the Soc. of Leather Technol. and Chem. 68:141-145.

Kaewruang, P., S, Benjakul, T. Prodpran, and S. Nalinanon. 2013. Physicochemical and functional properties of gelatin from the skin of unicorn leatherjacket (Aluterus monoceros) as affected by extraction condition. Food Bio Sci. 2: 1-9.

Karim, A.A. and R. Bath. 2009. Fish Gelatin; Properties, Chalenges and Prospect as an alternative to mammalian gelatin. Food Hydrocoll. 23: 563-576.

Kolodziesjka; E. Skierka., M.Sadowska., W. Kolodziesjka and C. Nieckowska. 2007. Effect of extracting time and temperature on yield of gelatin from different fish offal. Food Chem. 107:700-706.

Ktari. N., I. Bkhairia, M, Jridi, I. Hamza, B.S. Riadh and M. Nasri. 2014. Digestive acid protease from Zebra blenny (Salaria basilisca): Characteristics and application in gelatin extraction. Food Res. Int. 57:218-224

Kusumawati, R., Tazir and A. Wawasto. 2008. Pengaruh Perendaman dalam Asam Klorida terhadap kualitas Gelatin Tulang Kakap Merah (Lutjanus sp). J. Pasca Panen dan Bioteknologi Kelautan dan Perikanan. 3(1):
63-68

Muyonga, J.H., G.G.B. Cole and K.G. Duodo. 2004. Extracting and physicochemical characterization of Nile perch (Latec niloticus) skin and bone gelatin. Food Hydrocoll.18:581-592

Nagarajan, M., S. Benjakul, T.Prodptan, P. Songtipya and H. Kishimura. 2012. Characteristic and functional properties of gelatin from splendid squid (Loliga formasana) skin as affected by extraction temperature. Food Hydrocoll. 20: 389-397

Nikoo, M., S. Benjakul, M. Bashari, M. Alekhorshied, A.I. Cissouma, N. Yang and X. Xu. 2014. Physicochemical properties of skin gelatin from farmed amur sturgeon (Acipenser schrenckii) as influenced by acid pretreatment. Food Biosci.5:19-26

Niu, L., X. Zhiou., C. Yuan., Y. Bai., K., Lai., F. Yang and Y. Huang. 2013. Characterization of tilapia (Oreochromis niloticus) skin gelatin extracted with alkaline and different acid pretreatments. Food Hydrocoll. 3:336341

Ockerman, H.W and G. L. Hansen. 2000. Animal By-Product Processing and Utilization. CRC-Press

Pelu, H., S. Harwanti and E. Chasanah. 1998. Ekstraksi gelatin dari kulit ikan tuna melalui proses asam. J. Penelitian Perikananan Indonesia. 4(2):66-74.

Pranoto, Y., M.L. Chong and H.J. Park. 2006. Characterization of fish gelatin film added with gellan and $\kappa$-Carragenan. LWT- Food Sci. and Technol. 40:766-774.

Rahman, M.N.A and S.A.S.K.A., Jamalulail. 2012. Extractions, physicochemical characterizations and sensory quality of chicken feet gelatin. Borneo Sci. 30:1-13.

Said, M.I., J.C. Likadja and M. Hatta. 2011. Pengaruh waktu dan konsentrasi bahan curing terhadap kuantitas dan kualitas gelatin kulit kambing yang diproduksi melalui proses asam. Jurnal Ilmu dan Teknologi Peternakan. 1:119-128

Sae-Leaw, T and S. Benjakul. 2015. Physicochemical properties and fishy odour of gelatin from seabass (Lates calcarifer) skin stored in ice. Food Bio Sci. 10: 59-68

Sae-Leaw, T., S.Benjakul, and N.M. O'Brien. 2016. Effect of defatting and tannic acid incorporation during extraction on properties and fishy odour of gelatin from seabass skin. LWT-Food Sci. and Technol. 65:661-667. 
See, S. F., P.K. Hong, K.L. Ng, W.M. Wan Aida and A.S. Babji. 2010. Physicochemical properties of gelatin extracted from skins of different freshwater fish species. Int. Food Res. J. 17:809-816.

Shyni, K., G.S. Herma, G. Ninan, S. Mathew, S., Joshy and P.T. Lakshmanan. 2014. Isolation and characterization of gelatin from skins of Skipjack tuna (Katsuwonus pelamis), dog shark (Scoliodon sorrakowah), and rohu (Labela rohita). Food Hydrocoll.39: 68-76

Sithusamran, S., S. Benjakul and H. Kishimura. 2014. Characteristics and gel properties of gelatin from skin of Seabass (Lates calcarifer) as influenced by extraction condition. Food Chem. 152:276-284.

Sompie, M., S.E. Surtijono, J.H.W. Pontoh and N.N. Lontaan. 2015. The Effects of acetic acid concentration and extraction temperature on physical and chemical properties of pigskin gelatin. Proced. Food Sci. 3: 383-388.
Spanghero, M., L.Gracco, R. Valusso and Piasentier. 2004. In vivo performances, slaughtering traits and meat quality of bovine (Italia simmental) and buffalo (Italian Mediterranean) bulls. Livest. Prod. Sci. 91:120-141.

Uriarte-Montoya, M.H., H. Santacruz-Ortega, F.J.Cinco-Moroyoqui, O. Rouzaud-Sandez, M.Plascencia-Jatomea and J.M.EzquerraBrauer. 2011. Gian squid skin gelatin: Chemical composition and biophysical characterization. Food Res. Int. 44:32433249

Wang, L., A.M. Rau, J.F. Kerry, and J.P. Kerry. 2008. Effect of $\mathrm{pH}$ and addition of corn oil on the properties of gelatin based biopolymer film. J. Food Eng. 90:11-19.

Yakimates, I., N.Wellner, A.C. Smith, R.H.Wilson, I.Farhat and J. Mitchell. 2005. Mechanical properties with respect to water content of gelatin films in glassy state. Polym. 46:12577-12585. 